\title{
Transfigurações do passado: aspectos do problema do tempo na segunda Consideração extemporânea
}

\author{
Eduardo Nasser*
}

Resumo: A segunda Consideração Extemporânea foi acolhida no cenário filosófico contemporâneo como uma obra singular do pensamento nietzschiano que serve de marco na transição do tempo abstrato para o tempo vivido; sua maior virtude teria sido evidenciar o futuro enquanto um modo temporal dominante na existência humana. Contudo, pretendo mostrar que, nesse livro, Nietzsche está na verdade interessado em combater os efeitos devastadores da percepção do tempo para o homem - um problema que já o perseguia -, encontrando, para tanto, recursos preciosos numa apropriação valorativa da história.

Palavras-chave: tempo - vir-a-ser - história - valor - ciência - causalidade.

* Professor da Universidade Federal do ABC (UFABC), Brasil.

Correio eletrônico: e.nasser@ufabc.edu.br. 
Nasser, E.

\section{Recepção da segunda Consideração Extemporânea: uma nova visão sobre o tempo}

A segunda Consideração extemporânea, "Da utilidade e desvantagem da história para a vida", foi publicada em fevereiro de 1874, marcando o término de um curto, prolífico e atribulado período de composição ${ }^{1}$. Inicialmente, a segunda Extemporânea seria destinada ao problema da verdade, baseada em anotações contidas no caderno P I 20 que terminaram por anteceder a obra inacabada, e nunca publicada, Sobre verdade e mentira no sentido extramoral. Porém, em setembro de 1873 ocorre uma súbita mudança de rumo, fazendo com que Nietzsche passasse a se ocupar com o problema da história² ${ }^{2}$ Essa mudança deve ter provocado prejuízos nos planos editorais dessa obra, deixando ansiosos Nietzsche - que já começava a sofrer com seu estado de saúde declinante - e seu editor na época, Ernst Wilhelm Fritzsch ${ }^{3}$. Esse ambiente inquieto fica manifesto na escolha um tanto fortuita do título do livro - cuja inspiração deve ter vindo da obra Letters on the Study and Use of History (1735), de

1 A primeira menção de Nietzsche à segunda Extemporânea é feita numa carta dirigida a Wagner no final de setembro de 1873. Temendo pelo seu estado de saúde, que lhe impõe privações, Nietzsche diz que lhe resta somente a "reflexão", aptidão que será mobilizada para a sua segunda Extemporânea. (Cf. Carta para Richard Wagner, dia 18 de setembro de 1873, KSB 4. 157).

2 Cf. SALAQUARDA, Jörg. Studien zur Zweiten Unzeitgemässen Betrachtung in: Nietzsche Studien, 13, 1984, p. 5. Como destaca Jensen, não se trata, contudo, de uma ruptura substancial, existindo uma inegável conexão entre Sobre verdade e mentira no sentido extramoral com a segunda Extemporânea, especialmente nas seções intermediárias dessa obra. "Parece que o plano original de Nietzsche em 1873 era escrever duas obras: $V M$ para lidar com temas epistemológicos e $H V$ para tratar dos efeitos culturais da história contemporânea. Pouco depois $V M$ não surgiu, enquanto as seções intermediárias de $H V$ foram reformuladas para acolher temas epistemológicos. É no mínimo plausível, portanto, que $H V$ tenha absorvido e transformado as visões epistemológicas de $V M$ de uma maneira que tenha suplantado a intenção original de HV" (JENSEN, Anthony. An Interpretation of Nietzsche's On the Uses and Disadvantage of History for Life. New York: Routledge, 2016, p. 21). Eu retomarei posteriormente o debate acerca da continuidade das reflexões de Nietzsche sobre a história nessa obra, bem como nos escritos póstumos preparatórios, com a sua produção precedente.

3 Fritzsch, numa carta de outubro de 1873, diz a Nietzsche que aguarda o envio do manuscrito da segunda Extemporânea o quanto antes. Cf. Carta de Ernst Wilhelm Fritzsch, dia 19 de outubro de 1873, KGB II 4. 327.

$58 \mid$ Cad. Nietzsche, Guarulhos/Porto Seguro, v.38, n.2, p. 57-95, maio/agosto, 2017. 
Bolingbroke, e que seria alterado em $1887^{4}$-, no envio parcelado das seções - a seção 10 é iniciada em dezembro de 1873, sendo finalizada no dia 1 de janeiro de 1874, enquanto as seções $1-7$ já haviam sido impressas ( $C f$. Carta para Carl von Gersdorff, dia 26 de dezembro de 1873, KSB 4. 184. Carta para Carl von Gersdorff, dia 18 de janeiro de 1874, KSB 4. 192.) -, e, finalmente, no estilo e conteúdo das anotações preparatórias e da versão final, em que os sentidos de conceitos importantes revelam-se oscilantes e contraditórios, o que pode explicar o desejo imediatamente expresso por Nietzsche de incluir correções quando do recebimento da obra impressa - ele pretendia promover mudanças significativas, por exemplo, no segundo parágrafo do prólogo, tal como se pode constatar nas anotações presentes em sua cópia pessoal ${ }^{5}$.

A segunda Extemporânea foi gerada, portanto, num contexto de condições adversas, embrenhado pelo desassossego, tornando-a problemática aos olhos de Nietzsche, e também de seus primeiros leitores. Nesse período, Nietzsche possuía um pequeno e leal grupo de amigos e admiradores que não tardam em compartilhar com o autor as suas impressões acerca do novo livro. Os primeiros relatos, que chegam entre dezembro de 1873 e março de $1874^{6}$, são positivos: Gersdorff, Rohde, Wagner, Malwida von Meysenbug e Mathilde Maier externam grande deferência, parabenizando Nietzsche pela proeza $^{7}$. Mesmo Jacob Burckhardt, na época somente um colega

4 Há também a hipótese, menos provável, de Nietzsche ter sido influenciado pelo título da obra de Leon Battista Alberti, De commodis litterarum atque incommodes (1428). Em 1887, Nietzsche muda o título da segunda Extemporânea numa propaganda de suas obras já publicadas, chamando-a de Wir Historiker. Zur Krankheits-Geschichte der modernen Seele, o que expõe seu embaraço com o nome original. Cf. JENSEN, Anthony. Op. cit., pp. 10-12.

5 Cf. JENSEN, Anthony. Op. cit., p. 29.

6 Gersdorff, que fica responsável pela transcrição, e Rohde, revisor das provas, têm acesso à obra antes de sua publicação.

7 Cf. Carta de Carl von Gersdorff, dia 26 de dezembro de 1873, KGB II, 4. 362. Carta de Erwin Rohde, dia 9 de janeiro de 1874, KGB II, 4. 370 - 371. Carta de Richard Wagner, dia 27 de fevereiro de 1874, KGB II, 4. 396. Carta de Malwida von Meysenbug, dia 3 de março de 1874, KGB II, 4. 398 - 399. Carta de Mathilde Maier, dia 19 de março de 1874, KGB II, 4. 411.

Cad. Nietzsche, Guarulhos/Porto Seguro, v.38, n.2, p. 57-95, maio/agosto, 2017. 
Nasser, E.

de profissão por quem Nietzsche nutria enorme apreço intelectual, envia uma carta lacônica, porém simpática, em que revela suas limitações para compreender as causas, fins e expectativas das ciências históricas, enfatizando, de qualquer modo, o valor das reflexões nietzschianas ao confrontar o "antagonismo entre saber [Wissen] e poder [Können] históricos". Porém, no final de março de 1874, Nietzsche recebe duas cartas menos entusiasmadas: de Cosima e Rohde. Para Cosima, o novo livro não se equipara com as primeiras obras de Nietzsche em virtude de seu conteúdo extravagante e demasiado abstrato, tornando-o difícil de ser acessado pela maioria? É muito possível que Cosima esteja partilhando de forma mais polida a opinião negativa de Wagner a respeito da segunda Extemporânea; apesar de felicitar Nietzsche por sua obra recém-publicada, em segredo Wagner a desdenha por sua imaturidade, má distribuição, redundância, complexidade e falta de originalidade, já que a ideia principal havia sido previamente colocada por Schopenhauer ${ }^{\mathbf{1 0}}$. Rohde foi ainda mais severo em sua crítica. Atendendo ao chamado de um descontente e inseguro Nietzsche para uma exposição das falhas da segunda Extemporânea (Cf. Carta para Erwin Rohde, dia 15 de fevereiro de 1874, KSB 4. 202), Rohde redige uma longa carta em que esmiúça uma grande quantidade de problemas, em boa medida insistindo nos pontos levantados por Cosima: a obra padece com a ausência de deduções, clareza, organicidade - Rohde chega a usar os ingleses como exemplo de excelência lógica que deveria ser seguido -, ainda que não deixe de concordar com o pensamento do amigo sobre a história, que continua sendo precioso para iluminar a contradição daqueles que querem transformar a

8 Carta de Jacob Burckhardt, dia 25 de fevereiro de 1874, KGB II, 4. 395. Nietzsche fala dessa carta com orgulho para Gersdorff e Rohde. Cf. Carta para Carl von Gersdorff, fim de fevereiro de 1874, KSB 4. 205. Carta para Erwin Rohde, dia 19 de março de 1874, KSB 4. 211.

9 Cf. Carta de Cosima Wagner, dia 20 de março de 1874, KGB II, 4. 413.

10 Cf. REICH, Hauke. Rezensionen und Reaktionen zu Nietzsches Werken 1872 - 1889. Berlin/New York: Walter de Gruyter, 2013, p. 458.

$60 \mid$ Cad. Nietzsche, Guarulhos/Porto Seguro, v.38, n.2, p. 57-95, maio/agosto, 2017. 
filologia clássica em ciência histórica ${ }^{11}$. $\mathrm{O}$ impacto dessas duas cartas sobre Nietzsche foi devastador, precipitando o seu desejo de tomar distância dessa Extemporânea ${ }^{12}$. Não obstante a tentativa de Gersdorff em se contrapor a Rohde, reiterando sua opinião de que se trata de uma obra vigorosa e corajosa ${ }^{13}$, bem como o recebimento de elogios entusiásticos do livro, como aqueles concebidos pela desconhecida Emma Guerrieri-Gonzaga ${ }^{\mathbf{1 4}}$, somado, enfim, a algumas resenhas que tratam o livro com seriedade - especialmente a extensa resenha de Karl Hillebrand publicada em 1874 no Neue freie Presse, de que Nietzsche seguramente toma conhecimento ${ }^{\mathbf{1 5}}$-, Nietzsche parece estar convencido de que cometeu um engano com esse escrito, ocultando-o de sua herança literária nos anos posteriores. Isso fica evidente na segunda metade da década de 1880, quando ele descarta a possibilidade de uma nova edição dessa obra, e quando ele se compromete a discutir com alguns de seus interlocutores, mesmo que criticamente, a primeira, terceira e quarta Extemporânea, nunca a segunda. Somente em Ecce Homo a segunda Extemporânea volta a ser mencionada diretamente, e, ainda assim, muito brevemente ${ }^{\mathbf{1 6}}$.

11 Cf. Carta de Erwin Rohde, dia 24 de março de 1874, KGB II, 4. 421 - 424. Rohde já havia formulado críticas à segunda Extemporânea em troca de cartas com Gersdorff. Cf. KRUMMEL, Richard Frank. Nietzsche und der deutsche Geist I. Berlin/New York: Walter de Gruyter, 1998, p. 38.

12 Sobre a importância das cartas de Cosima e Rohde para explicar o mal-estar de Nietzsche com essa obra, Cf. SALAQUARDA, Jörg. Op. cit., p. 14.

$13 C f$. Carta de Carl von Gersdorff, dia 14 de abril de 1874, KGB II, 4. 443. Nietzsche havia enviado a Gersdorff a carta contendo as críticas de Rohde

$14 C f$. Carta de Emma Guerrieri-Gozaga, dia 5 de abril de 1874, KGB II, 4. 430 - 432. Emma cultua a segunda Extemporânea, ao contrário de $O$ nascimento da tragédia e a primeira Extemporânea, vendo ali uma "revelação" [Offenbarung] (Carta de Emma Guerrieri-Gozaga, dia 15 de maio de 1874, KGB II, 4. 471.

15 Cf. REICH, Hauke. Op. cit., pp. 460-473. Cf. Carta para Erwin Rohde, dia 14 de junho de 1874, KSB 4. 236. Posteriormente, em 1878, Nietzsche congratula Hillebrand por tudo aquilo que ele disse sobre seus escritos. Cf. Carta para Karl Hillebrand, meio de abril de 1878, KSB 5. 319.

$16 C f$. BROBJER, Thomas. Nietzsche's View of the Value of Historical Studies and Methods in: Journal of the History of Ideas, 65, 2, 2004, pp. 309 e 310.

Cad. Nietzsche, Guarulhos/Porto Seguro, v.38, n.2, p. 57-95, maio/agosto, 2017. | 61 
Nasser, E.

Em que pesem as citadas reações desapontadas, a repercussão acadêmica irrelevante na época, e o constrangimento do próprio Nietzsche, a verdade é que, junto de Assim falou Zaratustra, a segunda Extemporânea veio a se tornar a obra mais impactante do pensamento nietzschiano na primeira metade do século XX, mesmo que a magnitude desse impacto não tenha sido, até o momento, devidamente reconhecida e tematizada pelos estudos de recepção ${ }^{\mathbf{1 7}}$. O George-Kreis ${ }^{18}$, Troeltsch, Dilthey, Heidegger, Gadamer ${ }^{19}$, Benjamin, grupos e personalidades de inconteste relevância nas searas filosófica, científica e literária do século XX, concederam à segunda Extemporânea um lugar de destaque. Essa recepção, porém, não foi inteiramente concordante, sendo possível discernir ao menos dois ramos: um que identifica nessa obra o germe da assim chamada crise do historicismo, e outro que enxerga ali a fundação de uma nova concepção de tempo. Segundo Dilthey, que considera Nietzsche o filósofo mais profundo, mas também um diletante aliado à Lebensphilosophie, a segunda Extemporânea promove a negação da história pautada num subjetivismo extremo, redundando numa visão abstrata e vazia do homem (afinal, o homem não pode se conhecer sem a história) ${ }^{\mathbf{2 0}}$. Para Troeltsch, Nietzsche foi o primeiro a realmente

17 Jensen abordou a recepção imediata da segunda Extemporânea, limitando-se, num recorte temporal mais expandido, a indicar que a historiografia do século XX soube assimilar aspectos antipositivistas que guardam semelhanças com a tese nietzschiana expressa na obra de 1874. Cf. JENSEN, Anthony. Op. cit., pp. 157-183.

18 Cf. KAUfmann, Walter. Nietzsche. Philosopher, Psychologist, Antichrist. Princeton: Princeton University Press, 1974, p. 142.

19Johann Figl desenvolveu uma investigação bastante detalhada sobre a grande dívida da hermenêutica filosófica do século XX para com essa Extemporânea; Dilthey, Heidegger e Gadamer elaboram algumas de suas posições mais significativas mediante uma confrontação com essa obra de Nietzsche. $C f$. FIGL, Johann. Nietzsche und die philosophische Hermeneutik des 20.Jahrhunderts. Mit besonderer Berücksichtung Diltheys, Heideggers und Gadamers in: Nietzsche Studien, 10/11, 1981/82, pp. $408-441$.

20 Cf. DILTHEY, Wilhelm. Die drei Grundformen der Systeme in der ersten Hälfte des 19.Jahrhunderts in: Gesammelte Schriften Band IV. Stuttgart/Göttingen: B.G. Teubner/Vandenhoeck \& Ruprecht, 1974 , p. 528 e 529. Sobre a relação conflituosa de Dilthey com o pensamento nietzschiano, $C f$.

62 | Cad. Nietzsche, Guarulhos/Porto Seguro, v.38, n.2, p. 57-95, maio/agosto, 2017. 
Transfigurações do passado: aspectos do problema do tempo ...

compreender o problema da fundação dos valores quando se parte da história, fazendo com que ele engendre, em larga medida, a "crise e autorreflexão do historicismo moderno ${ }^{21 "}$. Para outros, sem embargo, a maior virtude dessa obra não foi o seu enfoque crítico, mas o fato de ter relacionado história e tempo, mostrando que, quando a história serve à vida, deixando de ser Historie para se tornar Geschichte, ela suprime o tempo quantitativo, absoluto, homogêneo, cronológico e indiferente das ciências naturais, descerrando o tempo kairótico, vivido e qualitativo. Deve-se atribuir destacado valor, nesse caso, ao acolhimento dado por Heidegger a essa Extemporânea.

No entender de Heidegger, toda a tradição ocidental, permeada pela metafísica da presença, foi subjugada pelo entendimento do tempo enquanto sucessão de agoras, uma concepção de tempo que foi paradigmaticamente expressa por Aristóteles na Física, mantendose inalterada na contemporaneidade, mesmo nas abordagens aparentemente mais heterodoxas de Hegel e Bergson ${ }^{22}$. Essa compreensão vulgar do tempo também envolve Nietzsche. Para Heidegger, Nietzsche não soube se esvair da pergunta condutora da

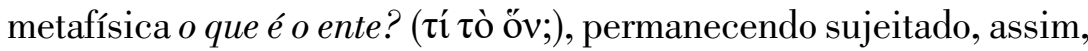
à representação aristotélica do tempo; "a resposta que Aristóteles oferece à pergunta formulada por ele sobre a essência do tempo determina ainda a representação do tempo em Nietzsche". Guiado por Aristóteles, que entende o tempo como um ente mediante o abalizamento de sua essência pelo agora (ṽ̃v, nunc), Nietzsche não pode senão apreender o tempo como passar, isto é, "como escoamento do sucessivo, como aproximação e distanciamento de todo agora,

STEGMAIER, Werner. Philosophie der Fluktuanz. Dilthey und Nietzsche. Göttingen: Vandenhoeck \& Ruprecht, 1992, pp. 65-110.

21 TROELTSCH, Ernst. Der Historismus und seine Probleme. Erstes Buch: Das logische Problem der Geschichtsphilosophie. Tübingen: J.C.B. Mohr, 1922, p. 140. Cf. SCHLEGEL, Wolfgang. Nietzsches Geschichtsauffassung. Würzburg: Konrad Triltsch, 1937, p. 3.

22 Cf. HEIDEGGER, Martin. Sein und Zeit in: Gesamtausgabe Band 2. Frankfurt am Main: Vittorio Klostermann, 1977, p. 24 e pp. 555 -575.

Cad. Nietzsche, Guarulhos/Porto Seguro, v.38, n.2, p. 57-95, maio/agosto, 2017. 
Nasser, E.

passando do 'ainda não agora' ao 'não mais agora' e, consequentemente, a caracterização do temporal enquanto passageiro [Vergänglichen] ${ }^{23}$ ". Por não ter se livrado completamente da metafísica, Nietzsche não soube reconhecer como uma tarefa própria o desenvolvimento de uma teoria do tempo original o suficiente para superar a concepção sedimentada no ocidente do tempo que passa. Não bastasse isso, o tempo também não deve ter sido um problema real para ele devido à escassez de escritos dedicados a esse tema ${ }^{24}$. Todavia, a posição de Heidegger acerca de Nietzsche nesse contexto é mais ambígua. Pois, se por um lado Nietzsche é tão somente um herdeiro da concepção tradicional de tempo, por outro ele é tratado como o precursor de um novo entendimento do tempo e da história; Nietzsche entrevê a temporalidade do Dasein em detrimento do tempo vulgar. É essa outra direção que se faz presente no $\$ 76$ de Ser e tempo, quando Heidegger se apropria de algumas das principais teses da segunda Extemporânea ${ }^{\mathbf{2 5}}$.

Muito embora Heidegger critique implicitamente a segunda Extemporânea na conferência de 1924, Der Begriff der Zeit, ao reprovar a tendência da época que se vale do supra-histórico - um dos conceitos fulcrais dessa Extemporânea -, revivificadora da tentação

23 HEIDEGGER, Martin. Was heisst Denken? In: Gesamtausgabe Band 8. Frankfurt am Main: Vittorio Klostermann, 2002, pp. 100 e 104.

24 $C$. . HEIDEGGER, Martin. Nietzsche I in: Gesamtausgabe Band 6.1. Frankfurt am Main: Vittorio Klostermann, 1996, pp. 310 e 311.

25 Um artifício semelhante é usado por Heidegger em suas preleções de 1937, O eterno retorno do mesmo. Heidegger sugere que o eterno retorno nietzschiano deve ser compreendido como o deslocamento de uma determinada visão do tempo, aquela em que o tempo é algo em si, um aglomerado de agoras que fluem para o observador, e cujo resultado imediato é o fatalismo, para uma outra em que "a temporalidade do tempo $d a$ eternidade que se exige pensar no retorno do mesmo é a temporalidade em que, antes de tudo, e pelo que sabemos, está no homem, na medida em que resoluto [entschlossen] ao futuro e conservando o sido, configura e suporta o presente". Assumindo-se que Nietzsche sabia muito mais do que publicou, evidencia-se que, com a doutrina do eterno retorno, o tempo se converte em instante da decisão. $C f$. HEIDEGGER, Martin. Nietzsche I in: Gesamtausgabe Band 6.1. Frankfurt am Main: Vittorio Klostermann, 1996, pp. 318, 319 e 357.

64| Cad. Nietzsche, Guarulhos/Porto Seguro, v.38, n.2, p. 57-95, maio/agosto, 2017. 
de escapar do tempo para conter os perigos do excesso de história ${ }^{26}$, em Ser e tempo essa obra se torna o veículo para o reencontro da historicidade autêntica e, com ela, a temporalidade autêntica ${ }^{27}$. Para Heidegger, a história não pode ser primordialmente uma ciência, como desejava Ranke, pois se trata de uma idiossincrasia do Dasein; a história não é um objeto observável, de forma que, se ela é assim concebida, trata-se de um resíduo da aceitação do tempo vulgar (tempo do relógio e o calendário). A historiografia está, com efeito, assentada na historicidade do Dasein, pois somente assim há passado; não são os documentos, monumentos, que viabilizam acesso ao passado, mas o caráter histórico do Dasein. E, em consequência, a história deriva, em seu caráter mais originário, da temporalidade do Dasein; "a análise da historicidade [Geschichtlichkeit] do Dasein busca mostrar que esse ente não é 'temporal' por ele estar na história, mas, inversamente, que ele só existe e pode existir historicamente por ser temporal no fundamento de seu ser ${ }^{28}$ ". A historicidade não passa de uma temporalidade mais concreta. Nesse sentido, Nietzsche teve o mérito, no início da segunda Extemporânea, de ter apontado para o entrelaçamento entre temporalidade e historicidade, desvendando sua constituição peculiar ${ }^{29}$. Valendo-se de um expediente da hermenêutica romântica - que supõe que um autor sabe muito mais do que aquilo que escreveu -, Heidegger acredita que a maior conquista dessa obra foi ter reconhecido que a história pode ser danosa à vida quando

26 Cf. HEIDEGGER, Martin. Der Begriff der Zeit in: Gesamtausgabe Band 64. Frankfurt am Main: Vittorio Klostermann, 2004, p. 123.

27 Cf. BRUSOTTI, Marco. Heidegger su storia monumentale e ripetizione. La seconda Considerazione Inattuale di Nietzsche in Essere e Tempo in: Metafisica e nichilismo. Löwith e Heidegger interpreti di Nietzsche. Bologna: Pendragon, 2006, pp. 127 e 128.

28 HEIDEGGER, Martin. Sein und Zeit in: Gesamtausgabe Band 2. Frankfurt am Main: Vittorio Klostermann, 1977, p. 498.

29 "Em seu modo de ver (de Heidegger), a única figura na tradição que compreendeu claramente a primazia do tempo para o pensamento histórico foi Nietzsche (...) O ensaio ex-temporâneo de Nietzsche revelou a significância do tempo para a compreensão da história" (BAMBACH, Charles. Heidegger, Dilthey and the Crisis of Historicism. Ithaca: Cornell University Press, 1995, pp. 251 e 254). 
Nasser, E.

tomada em sua impropriedade, que obscurece a temporalidade do Dasein ao impor estaticidade, estratificação e objetivação aos modos do tempo (passado - presente - futuro); mas também vantajosa quando própria, incitando à dinamização, unificação e reconhecimento do tempo como temporalidade inerente ao Dasein. Nietzsche soube caracterizar esse modo próprio com os três tipos de historiografias que, quando unificados, deslindam o vínculo dos êxtases temporais: o passado (história antiquária) em aliança com o futuro (história monumental) que, quando repetido enquanto possível, imprime despresentificação (história crítica). Considerando-se que, aos olhos de Heidegger, há preeminência do futuro, então a história monumental deve gozar de prioridade ${ }^{\mathbf{3 0}}$.

Heidegger faz com que a segunda Extemporânea se torne uma obra pioneira por relacionar temporalidade e historicidade, além de exibir, nessa conjuntura, a primazia da práxis sobre a teoria. Em 1938 - 39, Heidegger retorna a essa obra num curso oferecido em Freiburg, Zur Auslegung von Nietzsches II. Unzeitgemässer Betrachtung, agora num outro contexto filosófico, posterior à Kehre, e com um tom um pouco mais crítico: esse livro é uma interpelação, não possuindo a forma de uma reflexão definitiva, e Nietzsche, mais preocupado com a vida do que exatamente a história, não realizou uma distinção apropriada entre Geschichte e Historie; porém, é inegável que a discussão levantada ali facilita essa distinção, não perdendo, portanto, sua importância ${ }^{31}$. Seja como for, a verdade é que, após a abordagem heideggeriana, a segunda Extemporânea passa a ser vista como um marco na transição do tempo abstrato para o tempo vivido. Como dirá Werner Gent em seu estudo dedicado às filosofias do tempo e espaço no século XIX, o estabelecimento do tempo vivido por Jonas Cohn

30 Cf. HEIDEGGER, Martin. Sein und Zeit in: Gesamtausgabe Band 2. Frankfurt am Main: Vittorio Klostermann, 1977, pp. 523 e 524.

31 HEIDEGGER, Martin. Zur Auslegung von Nietzsches II. Unzeitgemässer Betrachtung: "Vom Nutzen und Nachteil der Historie für das Leben" in: Gesamtausgabe Band 46. Frankfurt am Main: Vittorio Klostermann, 2003, pp. 9, 76 e 255.

$66 \mid$ Cad. Nietzsche, Guarulhos/Porto Seguro, v.38, n.2, p. 57-95, maio/agosto, 2017. 
Transfigurações do passado: aspectos do problema do tempo ...

converge com Nietzsche que, na segunda Extemporânea, oferece um novo aporte ao debate. Pode-se afirmar que Nietzsche, com essa Extemporânea, é, ao lado de Kierkegaard, o pai “da doutrina do tempo do mais novo desenvolvimento da pesquisa fenomenológica ${ }^{32}$ ". Ele se torna, assim, uma figura emblemática, talvez até mesmo mais do que Bergson ${ }^{33}$. Isso pode explicar a importância da segunda Extemporânea para um dos escritos mais seminais sobre o assunto no século XX: Sobre o conceito de história, de Benjamin. Para amparar o seu messianismo revolucionário contra a modernidade, Benjamin desenvolve o Jetztzeit em detrimento do tempo contínuo e progressivo, encontrando, para tanto, relevante estímulo na obra de Nietzsche sobre história. Para se ter uma ideia de sua pertinência, Benjamin usou um trecho dessa Extemporânea como epígrafe, simplesmente não concebendo Sobre o conceito de história sem ela; essa epígrafe sofre deslocamentos, mas em nenhum momento foi suprimida, mesmo quando Benjamin, no manuscrito francês de seu escrito, decide retirar todas as demais ${ }^{\mathbf{3 4}}$.

O fato de a segunda Extemporânea ter se tornado uma fonte de inestimável riqueza para algumas das mais importantes reflexões filosóficas sobre o tempo e história na contemporaneidade fez com que essa obra tenha também exercido destacada atração sobre os

32 GENT, Werner. Die Raum-Zeit-Philosophie des 19.Jahrhunderts II. Die Geschichte der Begriffe des Raumes und der Zeit vom kritischen Kant bis zur Gegenwart. Hildesheim: Georg Olms, 1971, pp. 336-339.

33 Para filósofos como Heidegger e Horkheimer, o projeto bergsoniano, que almeja expor o tempo qualitativo, fracassa devido à sua metafisica da duração, que tão somente inverte a concepção tradicional de tempo e que abstrai a história humana. $C f$. HEIDEGGER, Martin. Sein und Zeit in: Gesamtausgabe Band 2. Frankfurt am Main: Vittorio Klostermann, 1977, pp. 570 e 571. HORKHEIMER, Max. Zu Bergsons Metaphysik der Zeit in: Gesammelte Schriften Band 3. Frankfurt am Main: Fischer Taschenbuch, 1988, pp. 225-248. Ressalte-se, todavia, que Heidegger reconheceu a importância de Bergson em alguns de seus cursos. Cf. MASSEY, Heath. The Origin of Time. Heidegger and Bergson. New York: Suny Press, 2015, p. 88.

34 Cf. BENJAMIN, Walter. Über den Begriff der Geschichte in: Gesammelte Schriften I. Frankfurt am Main: Suhrkamp, 1994, p. 700. MCFARLAND, James. Constellation. Friedrich Nietzsche and Walter Benjamin in the Now-Time of History. New York: Fordham University Press, 2013, p. 243.

Cad. Nietzsche, Guarulhos/Porto Seguro, v.38, n.2, p. 57-95, maio/agosto, 2017. 
Nasser, E.

estudos especializados de Nietzsche, acima de tudo em meados do século passado, como se faz notar nos célebres comentários de Jaspers, Kaufmann e Müller-Lauter. Há, porém, um problema considerável, para o qual eu desejo chamar a atenção, nos estudos que se deixaram influenciar em demasia pela recepção exultante dessa Extemporânea na primeira metade do século XX, particularmente a apropriação heideggeriana. As pioneiras investigações sobre tempo e história em Nietzsche, empreendidas por Stambaugh, Bulhof e Fleischer, exibem esse problema com clareza ${ }^{\mathbf{3 5}}$. Partindo direta ou indiretamente de Heidegger $^{\mathbf{3 6}}$, esses estudos tomam a segunda Extemporânea como o momento em que Nietzsche se volta pela primeira vez, com intrepidez, para o problema do tempo ${ }^{37}$, aceitando a asserção heideggeriana que reconhece na tripartição nietzschiana da história uma correspondência exata com os três modos temporais ${ }^{\mathbf{3 8}}$, uma ordenação desigual cuja

35 Cumpre sublinhar que a influência de Heidegger nesse cenário de discussão é ainda mais abrangente. Jensen menciona os estudos de Karl-Heinz Volkman-Schluck, Leben und Denken: Interpretationen zur Philosophie Nietzsches (1968) e de Hartmut Schröder, Historische theorie und geschichtliches Handeln: Zur Wissenschaftskritik Nietzsches (1982), que corroboram grande parte do conteúdo sobre Nietzsche apresentado no $\$ 76$ de Ser e tempo. Cf. JENSEN, Anthony. Op. cit., n. 22, p. 85.

360 interlocutor de Bulhof é Heidegger, que não enxergou quão profundamente Nietzsche esteve envolvido com os problemas do tempo e da história devido à sua caracterização da filosofia nietzschiana enquanto manifestação da técnica; para Bulhof, Nietzsche chega a uma "nova concepção de tempo que está em íntima relação com a história" (BULHOF, Ilse Nina. Apollos Wiederkehr. Eine Untersuchung der Rolle des Kreises in Nietzsches Denken über Geschichte und Zeit. Den Haag: Martinus Nijhoff, 1969, p. 13). Fleischer pretende dar prosseguimento à interpretação da segunda Extemporânea realizada por Heidegger no $\$ 76$ de Ser e tempo, acrescentando que Nietzsche expressou o que compreendeu, chegando muito próximo do que os filósofos do presente pensam sobre a temporalidade e historicidade do homem. Cf. FLEISCHER, Margot. Die Zeitlichkeit des Menschen. Nietzsche Analyse in seiner zweiten Unzeitgemässen Betrachtung in: BEIERWALTES, Werner, SCHRADER, Wiebke (Hrsg.) Weltaspekte der Philosophie. Rudolf Berlinger zum 26. Oktober 1972. Amsterdam: Rodopi NV, 1972, p. 68.

37 "O problema do tempo enquanto tal aparece primeiramente para Nietzsche na segunda das Considerações extemporâneas, quando ele começa a refletir sobre a essência do histórico" (STAMBAUGH, Joan. Untersuchungen zum Problem der Zeit bei Nietzsche. Den Haag: Martinus Nijhoff, 1959, p. 20). Bulhof também elege como ponto de partida de sua pesquisa essa Extemporânea; para Bulhof, o debate sobre história e tempo é iniciado nessa obra, sendo concluído em Assim falou Zaratustra. Cf. BULHOF, Ilse. Op. cit., pp. 14 e 79.

38 O esquema proposto por Heidegger (história monumental/futuro; história antiquária/passado; história crítica/presente) é reproduzido por Stambaugh. Cf. STAMBAUGH, Joan. Op. cit., p. 42.

68 Cad. Nietzsche, Guarulhos/Porto Seguro, v.38, n.2, p. 57-95, maio/agosto, 2017. 
supremacia deve ser reservada para a história monumental e o futuro $^{39}$. Mas, complacentes com a interpretação heideggeriana, essas investigações também ratificam seus equívocos. Como bem indica Brusotti, quando Heidegger atribui ao futuro, ou à história monumental, a realização da história autêntica, ele está, na verdade, valendo-se da concepção kierkegaardiana de repetição, que significa repetição da possibilidade, e não tão somente repetição do passado ${ }^{\mathbf{4 0}}$. No meu entender essa confusão conceitual criou um impedimento para determinar o real propósito de Nietzsche em suas reflexões sobre história e tempo nessa época. Tal como pretendo demonstrar, na segunda Extemporânea, bem como em suas anotações preparatórias, contidas no caderno U II 2, Nietzsche busca encontrar na história recursos profundamente antimodernos para neutralizar o vir-a-ser, solucionando um problema que já o perseguia. Por diferentes razões, Stambaugh e, mais recentemente, Brobjer e Jensen, sustentam que o livro de Nietzsche sobre história, de 1874, é um tipo de desencaminho, não possuindo real vinculação com a produção que lhe antecede ${ }^{\mathbf{4 1}}$.

Bulhof também subscreve esse esquema, mas com alterações (história monumental/presente; história antiquária/passado; história crítica/futuro). Cf. BULHOF, Ilse Nina. Op. cit., p. 36.

39 Stambaugh dirá que Nietzsche, nesse livro, distingue tempo do vir-a-ser e tempo histórico, cujos correlatos temporais são, respectivamente, passado e futuro. Com isso, haveria uma superioridade da história monumental, o tipo de história que verdadeiramente contém o futuro. "É claramente a história monumental que possui a maior possibilidade para a "vida"' (STAMBAUGH, Joan. Op. cit., p. 42). Para Fleischer, Nietzsche se afasta aí da concepção tradicional do tempo através da unificação da força do esquecimento e da força plástica que geram uma terceira força, a paixão, responsável por abrir o futuro, que se junta ao instante, dissolvendo, assim, "a interpretação do tempo enquanto fluxo de agoras" (FLEISCHER, Margot. Op. cit., p. 74).

40 BRUSOTTI, Marco. Op. cit., pp. 137-141.

41 Como eu já disse, Stambaugh julga que a segunda Extemporânea contém as primeiras reflexões de Nietzsche sobre o tempo. Anteriormente, mais especificamente em $O$ nascimento da tragédia, "o tempo não possui ainda um papel constitutivo", sendo "mencionado somente de passagem" (STAMBAUGH, Joan. Op. cit., p. 20). Para Brobjer, Nietzsche, salvo em seu escrito de 1874, foi um grande apreciador do historicismo, adotando sua rigorosa metodologia crítica. Desse modo, a segunda Extemporânea deve ser vista como um desvio transitório. Cf. BROBJER, Thomas. Nietzsche's Relation to Historical Methods and Nineteenth-Century German Historiography in: History and Theory, 46, 2007, p. 178. No entender de Jensen, essa Extemporânea não possui conexão com $O$ nascimento da tragédia, mas com Sobre verdade e mentira no sentido extramoral. Ademais, contra Brobjer, Jensen alega que muito do conteúdo dessa obra perdura no pensamento nietzschiano. $C f$.

Cad. Nietzsche, Guarulhos/Porto Seguro, v.38, n.2, p. 57-95, maio/agosto, 2017. 
Nasser, E.

Eu desejo alegar, diferentemente, que existe uma forte ligação com as reflexões precedentes que buscavam escapar do vir-a-ser mediante artifícios supra-históricos: a filosofia, a arte e a religião. Nietzsche se defronta, por certo, com um novo e inquietante horizonte teórico nesse momento: o inevitável reconhecimento da realidade do vir-a-ser. Tal como eu já defendi, é em 1873, na obra nunca publicada A filosofia na idade trágica dos gregos, que Nietzsche é forçado a reconhecer a realidade do vir-a-ser, em contraposição ao idealismo temporal que, até então, contava com seu suporte intelectual ${ }^{42}$. Esse episódio enceta uma profunda revisão de boa parte de suas convicções filosóficas, cujo efeito mais concreto passa a ser perceptível em Humano, demasiado humano, não sendo, contudo, ignorado na Extemporânea de 1874; num trecho de surpreendente franqueza desse livro, Nietzsche diz que toma "a doutrina do vir-a-ser soberano", ainda que mortífera, por uma verdade (Cf. HL/Co. Ext. II, 9, KSA 1.319). Todavia, se essa verdade não pode ser esquecida, se o homem não pode suplantar sua historicidade, não sendo mais justo somente adentrar na trilha supra-histórica, a sua força destrutiva pode, ao menos, ser diminuída através de uma utilização astuta da história.

\section{Sub specie aeterni, sub specie saeculi}

Nietzsche foi educado num ambiente conflituoso, permeado pela disputa entre fé religiosa irracional e a mentalidade racional, científica, que reivindica um tratamento das escrituras através do método histórico-crítico. Num primeiro momento, tal como eu já propus, Nietzsche busca por uma saída conciliatória ${ }^{\mathbf{4 3}}$; mas ele vai se

JENSEN, Anthony. Op. cit., pp. 20-22, 62 e 162. Destaque-se que essa é também a visão de Emden, para quem a segunda Extemporânea representa o primeiro passo rumo ao projeto genealógico. Cf. EMDEN, Christian J. Friedrich Nietzsche and the Politics of History. Cambridge: Cambridge University Press, 2008, pp. 139 e 140.

42 Cf. NASSER, Eduardo. Nietzsche e a ontologia do vir-a-ser. São Paulo: Loyola, 2015, pp. 43-45. 43 Cf. NASSER, Eduardo. Sul cristianesimo del giovane Nietzsche in: BUSELLATO, Stefano (Org.)

$70 \mid$ Cad. Nietzsche, Guarulhos/Porto Seguro, v.38, n.2, p. 57-95, maio/agosto, 2017. 
indispondo progressivamente com a ciência histórica em virtude de

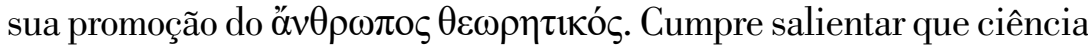
histórica está aqui conectada a nomes como Wolf, Niebuhr, Ranke e Mommsen ${ }^{44}$. Isso pode esclarecer as razões que levam Nietzsche a identificar na ciência histórica o correlato no mundo humano da ciência natural, sem discorrer acerca da querela metodológica que prepara a distinção entre Natur e Geisteswissenschaften, já iniciada por Droysen ${ }^{45}$. Nietzsche deve estar pensando em observações como as de Niebuhr que, buscando orientação nas ciências exatas, compara o seu trabalho ao do anatomista ${ }^{\mathbf{4 6}}$.

$\mathrm{O}$ historicismo e as ciências natureza exigem que tudo deve ser explicado, fixando a cultura do homem teórico que, desde Sócrates, exerce dominação sobre o ocidente. Trata-se de uma força enfraquecedora que impede a elevação da cultura e ameaça a existência humana. O maior dano é que, ao se deterem somente nas aparências, as ciências naturais e históricas ficam com o que passa, ao invés do essencial e eterno, arremessando o homem no tempo, que Nietzsche entende como Kronos, o tempo que devora seus próprios filhos (Cf. Nachlass/FP, 5[28], KSA 7.99). A esse respeito, o § 23 de $O$ nascimento da tragédia é bastante rico. Nietzsche conta ali mostrar que a modernidade, penetrada pelo "espírito histórico crítico",

Nietzsche dal Brasile. Contributi alla ricerca contemporanea. Pisa: Edizioni ETS, 2014, pp. 147-164.

44 Segundo Brobjer, Nietzsche leu obras de todos os nomes citados. Cf. BROBJER, Thomas. Nietzsche's View of the Value of Historical Studies and Methods in: Journal of the History of Ideas, 65, 2, 2004, p. 165.

45 “O primeiro sentido de 'historicismo' é positivismo em relação às ciências humanas: a acumulação livre de valores de materiais e fatos sem distinção entre o que é e o que não é importante, que, não obstante, reivindica objetividade científica" (SCHNÄDELBACH, Herbert. Philosophy in Germany 1831 - 1933. Trad. Eric Matthews. Cambridge: Cambridge University Press, 2009, p. 35). Nietzsche correlaciona história e ciências naturais desde 1862. Cf. Fado e história, KGW I, 2. 432. Cf. também: Nachlass/FP, 19[23], KSA 7. 423. Nachlass/FP, 19[38], KSA 7.430.

46 Cf. GUILLAND, Antoine. Modern Germany \& Her Historians. New York: Mcbride, Nast \& Company, 1915, p. 52. Eu já indiquei que Wolf funda a filologia enquanto ciência da antiguidade baseandose nas ciências naturais. $C f$. NASSER, Eduardo. Nietzsche et la réforme méthodologique de la philologie: le problème de la scientificité dans le contexte des études classiques in: DENAT, Céline, WOTLING, Patrick (Org.) Nietzsche. Les premiers textes sur les Grecs. Reims: Épure, 2016, p. 55.

Cad. Nietzsche, Guarulhos/Porto Seguro, v.38, n.2, p. 57-95, maio/agosto, 2017. $\mid 71$ 
Nasser, E.

não pode ter acesso à experiência estética legítima, tornando-a desprovida do mito. Mas ao se emancipar do mito, a modernidade também perde o refúgio da eternidade. Os povos resguardados pelo mito vivem sub specie aeterni, reconhecendo a "relatividade do tempo" e o "significado verdadeiro, isto é, metafísico da vida". Em contrapartida, os povos sem mitos, reduzidos à história, glorificam somente uma descontrolada vontade de conhecer, restringindo-se a uma existência sub specie saeculi, do "tempo do agora" [Jetztzeit] (Cf. GT/NT 23, KSA 1.145-149). Inspirando-se muito provavelmente em Schopenhauer, para quem o tempo é essencialmente sucessão, fuga constante, Nietzsche entende aqui por tempo do agora o grau mais extremo da impermanência; pois presente significa um "limite sem extensão e sem duração" entre passado e futuro ${ }^{47}$. Assim, o homem que vive no agora é constantemente ameaçado pelo aniquilamento, pelo não-ser.

O diagnóstico que Nietzsche faz da modernidade, dominada pela perspectiva historicista e naturalista, é que se trata de uma cultura arruinada em virtude de seu aprisionamento ao vir-a-ser. Os instintos místicos são desarticulados pelo "gênio teórico" que, através do emprego desmedido da causalidade, das palavras e conceitos, exacerba as forças apolíneas, impedindo a experiência da eternidade (Cf. Nachlass/FP, 7[125], KSA 7.182) ${ }^{\mathbf{4 8}}$. Assim, a figura mais exaltada nessa cultura deteriorada passa a ser do jornalista, o "servo do instante [Augenblick]", o "escravo do dia, atado pela corrente do instante e faminto - sempre faminto" (BA/EE, KSA 1.671 e 747), o constrangedor paradigma que guia os eruditos e filósofos universitários. Todavia, não se trata de um quadro irreversível. $\mathrm{O}$ pessimismo nietzschiano em relação à modernidade contrasta com

47 SCHOPENHAUER, Arthur. Die Welt als Wille und Vorstellung I. Stuttgart: Suhrkamp, 1986, p. 36. Em seu capítulo dedicado a Heráclito, contido em A filosofia na idade trágica dos gregos, Nietzsche parafraseia o trecho mencionado de Schopenhauer, sem indicar a obra. Cf. PHG/FT, KSA 1.823 e 824.

48 Com o ớv $\theta \rho \omega \pi \circ \varsigma \theta \varepsilon \omega \rho \eta \tau \iota \kappa o ́ \varsigma$, "o elemento apolíneo se separa novamente do dionisíaco" (Nachlass/ FP, 7[7], KSA 7.138).

72 | Cad. Nietzsche, Guarulhos/Porto Seguro, v.38, n.2, p. 57-95, maio/agosto, 2017. 
suas expectativas de uma restauração da relação com a eternidade através da estética. A arte deve ser promovida como um ideal cultural que viabiliza o "retorno à vida", sucedendo a "história e as ciências naturais" que, contra a idade média, instituíram "o saber [Wissen] contra a crença" (Cf. Nachlass/FP, 19[38], KSA 7.430). Isso requer, primeiro, uma reeducação epistemológica municiada pelo idealismo transcendental, que aponta para a idealidade do tempo e, no limite, para o caráter relativo do conhecimento. Trata-se de uma etapa preparatória, destinada por Nietzsche, sobretudo, aos filólogos e historiadores ${ }^{49}$. Sua maior virtude é moderar o impulso de conhecimento do homem teórico e, até mesmo, cessá-lo. Cria-se, assim, um terreno fértil para o surgimento dos gênios redentores do instante (Cf. BA/EE, KSA 1.671), que concernem, sobretudo, o gênio artístico e o gênio filosófico ${ }^{\mathbf{5 0}}$.

A arte, cuja manifestação mais genuína é a música, coloca-se para além do campo das abstrações, alcançando, com a sua natureza simbólica, o plano do não-histórico, o atemporal. A excelência da arte está no fato de submergir no irracional, livre do conhecimento, da causalidade e, assim, do tempo (Cf. Nachlass/FP, 7 [127], 9[90] e 9[92], KSA 7.186 e 187; 307 e 308). O mesmo não acontece com a filosofia. A filosofia deve ser situada entre arte e ciência. Como o cientista, o filósofo recorre a conceitos e raciocina por meio de causas e efeitos; mas, como o artista, ele poetiza com os conceitos, construindo sistemas cujo valor é estético (Cf. Os filósofos pré-platônicos, KGW II, 4. 218. Nachlass/FP, 19[62], KSA 7.439). Nietzsche pensa aqui num tipo muito particular de filósofo, o filósofo do conhecimento trágico,

$49 C f$. NASSER, Eduardo. Nietzsche et la réforme méthodologique de la philologie: le problème de la scientificité dans le contexte des études classiques in: DENAT, Céline, WOTLING, Patrick (Org.) Nietzsche. Les premiers textes sur les Grecs. Reims: Épure, 2016, pp. 51-77. Cf. também: GT/ NT 18, KSA 1.115-120.

50 O gênio religioso, o santo, também é evocado, mas com menos ênfase. Isso se deve, muito possivelmente, aos efeitos da Crítica da razão pura, pois, segundo Nietzsche, após essa obra, é impossível recriar a religião que deve, então, ceder lugar ao valor estético engendrado pelo filósofoartista. Cf. Nachlass/FP, 19[39], KSA 7.431.

Cad. Nietzsche, Guarulhos/Porto Seguro, v.38, n.2, p. 57-95, maio/agosto, 2017. 
Nasser, E.

aquele que reconhece com lamentação o aspecto trágico contido na crítica do conhecimento, que culmina na destruição da metafísica teórica, e que se ocupa, na esperança de conter o ceticismo, com a elaboração de imagens conceituais de mundo que provoquem efeitos similares ao da arte (Cf. Nachlass/FP, 19[35], KSA 7.427 e 428). Apesar de compartilhar com o cientista o discurso lógico, o verdadeiro filósofo, ao invés do filósofo universitário, está comprometido com forças ilógicas que amparam o surgimento de uma cultura artística, entretendo-se com os "problemas eternos", em contraposição à história e às ciências naturais (Cf. BA/EE, KSA 1. 742. Nachlass/ FP, 19[23], KSA 7. 423). A maneira como Nietzsche retrata Tales é emblemática. Tales é o primeiro a fornecer uma visão sistemática de mundo, extraindo, de um princípio, consequências gerais. É certo que essa visão sistemática já era promovida na antiguidade pelas cosmogonias. Porém, ao contrário do poeta, Tales emprega conceitos. Isso também faz com que ele não possa mais fazer parte do que Nietzsche chama de estágio dos sábios, adeptos da forma esporádico-sentenciosa; Tales fornece uma visão de totalidade, em que tudo está conectado - uma imagem de mundo. A sofia de Tales reside aqui justamente nesse talento, o que faz com que não se possa rotulá-lo como um homem inteligente. Sofia deve ser separada da inteligência, pois enquanto a inteligência obedece ao primado da tradução do fenômeno em esquemas compreensíveis, úteis (e lembremo-nos aqui da concepção schopenhaueriana de inteligência), a sofia produz um tipo de saber inútil, contemplativo (Cf. Os filósofos pré-platônicos, KGW II, 4.216-219). Quando uma filosofia adquire estatuto contemplativo, transforma-se em obra de arte, tendo, presumivelmente, o mesmo poder de deter os efeitos devastadores do vir-a-ser.

74| Cad. Nietzsche, Guarulhos/Porto Seguro, v.38, n.2, p. 57-95, maio/agosto, 2017. 
Transfigurações do passado: aspectos do problema do tempo ...

\section{História e a luta contra o tempo}

Em sua segunda Extemporânea, Nietzsche dá continuidade às discussões acerca da ameaça do vir-a-ser para os indivíduos e a cultura, igualmente responsabilizando as ciências históricas por exacerbar essa ameaça. Porém, diferentemente dos escritos anteriores, as ciências históricas não são acusadas de unicamente intensificar uma visão dinamizada do universo humano, mas de manter uma relação objetiva e racionalizada com o passado, prejudicando uma mobilização ativa da história que pode abrandar o fluxo do tempo.

Em seu primeiro esboço, a segunda Extemporânea se iniciava com uma seção em que Nietzsche explana a natureza da temporalidade humana através de uma comparação com os animais; os trechos que compõem o prefácio, na versão final, foram ulteriormente adicionados (Cf. Nachlass/FP, 30[1] e 30[2], KSA 7.725-732) ${ }^{51}$. Eu gostaria de sugerir que essa seção cumpre um papel organizador na obra, de tal modo que boa parte do que vem a seguir é uma resposta para o problema que é ali colocado.

Considera o rebanho que passa ao seu lado pastando: ele não sabe o que é ontem e o que é hoje; ele salta aqui e ali, come, descansa, digere, salta de novo e, assim, de manhã até a noite e dia após dia, ligado de maneira fugaz com seu prazer e desprazer, com a estaca do instante [Augenblick] e, por isto, nem melancólico e nem entediado [überdrüssig]. Ver isto é duro para o homem porque ele se vangloria de sua humanidade frente ao animal, embora olhe invejoso para a sua felicidade - pois ele quer apenas isso, viver como o animal, sem tédio e tampouco melancolia, e o quer, entretanto, em vão, porque não quer como o animal. $O$ homem pergunta uma vez ao animal: por que não me falas sobre tua felicidade e apenas me observas? $\mathrm{O}$ animal quer também responder dizendo-lhe que isso se deve ao fato de que eu sempre esqueço o que queria dizer - mas também já esqueceu essa resposta e silencia: de tal modo que o homem se admira disso. Todavia ele também se maravilha consigo mesmo por não poder aprender a esquecer e por sempre ser novamente preso ao que passou: por mais longe e rápido

$51 C f$. JENSEN, Anthony. Op. cit., p. 22.

Cad. Nietzsche, Guarulhos/Porto Seguro, v.38, n.2, p. 57-95, maio/agosto, 2017. |75 
Nasser, E.

que ele corra, a corrente corre junto. É um milagre: o instante rapidamente está aí, rapidamente já passou, antes um nada, depois um nada, retorna, entretanto, ainda como um fantasma e perturba a tranquilidade de um instante posterior. Incessantemente uma folha se destaca da roldana do tempo, cai e é carregada pelo vento - e, de repente, é trazida de volta para o colo do homem. Então o homem diz: "eu me lembro", e inveja o animal que imediatamente esquece e vê todo instante realmente morrer imerso em névoa e noite, desaparecendo para sempre. Assim, o animal vive a-historicamente: ele passa pelo presente como um número, sem deixar ruptura. Ele não sabe disfarçar, não esconde nada e aparece a todo o momento [Momente] plenamente como o que é, ou seja, não pode ser outra coisa senão sincero. $\mathrm{O}$ homem, ao contrário, contrapõe-se ao grande e cada vez maior ônus do que passou: este o oprime ou o inclina para o seu lado, incomodando seus passos como um fardo invisível e obscuro que ele pode por vezes aparentemente negar e que, no convívio com seus iguais, nega com prazer: para lhes despertar inveja. Por isso o aflige, como se pensasse em um paraíso perdido, ver o rebanho pastando ou, em uma proximidade mais familiar, a criança, que ainda não tem nada a negar de passado e brinca entre as cercas do passado e do futuro em uma bem-aventurada cegueira. E, no entanto, é preciso que sua brincadeira seja perturbada: para cedo demais ser chamada [heraufgerufen] para fora do esquecimento. Então ela aprende a entender a palavra "foi assim" [es war], aquela senha através da qual a luta, o sofrimento e o tédio se aproximam do homem para lembrá-lo o que é no fundo sua existência - um imperfectum que nunca pode ser preenchido. Se a morte traz enfim o desejado esquecimento, ela suprime ao mesmo tempo o presente e a existência, imprimindo, com isto, o selo sobre aquele conhecimento de que a existência é apenas um ininterrupto ter sido, uma coisa que vive de se negar e de se consumir, de se autocontradizer (HL/Co. Ext. II, 1, KSA 1.248 e 249).

O traço distintivo do tempo humano é a repetição; é o vento que traz de volta a folha que se destacou da roldana do tempo. Os instantes não só passam, mas se repetem, de modo que só assim há "foi assim" (e, consequentemente, a história). O animal, por seu turno, desconhece a repetição e, portanto, o tempo. $\mathrm{O}$ animal está imerso no instante, que aqui significa ausência de tempo. Diferencia-se 
Transfigurações do passado: aspectos do problema do tempo ...

do tempo do agora, tal como foi examinado acima, pois sequer está localizado entre passado e futuro.

Essa meditação sobre o tempo é de grande importância para o homem, pois é por ter um passado que ele realmente se diferencia dos animais. Quando Nietzsche assegura que toma a doutrina do vir-a-ser soberano como uma verdade, tal como vimos, isso inclui o assentimento às abordagens evolucionistas que defendem a "ausência de toda cardinal diferença entre homem e animal" (HL/Co. Ext. II, 9, KSA 1.319). Contudo, se não existe uma diferença substancial entre homem e animal, quer pela razão quer pela alma, há uma diferença de percepção do tempo - é a capacidade de se lembrar que faz com que o homem não seja um animal. Isso é tanto motivo de júbilo quanto aflição. Pois embora o homem fique intrigado e orgulhoso com esse "milagre" que o acomete, sentindo-se único, ele logo percebe que também é uma desgraça, porquanto a repetição do instante faz com que só possa ver a si mesmo em sua incompletude, o que estimula as emoções negativas do tédio e melancolia. Poder-se-ia supor que, desse modo, Nietzsche está demandando um retorno à natureza, recomendando ao homem tomar a vida a-histórica do animal como um fim a ser concretamente perseguido, pois o livraria do sofrimento causado pelo tempo. Essa foi, por exemplo, a compreensão que Löwith teve da passagem em discussão ${ }^{\mathbf{5 2}}$. Entretanto, eu procurarei mostrar que não é esse o caso.

Um amparo significativo pode ser encontrado no estudo de fontes. Investigações especializadas já revelaram que Nietzsche se beneficiou de Schopenhauer - no capítulo 38 do segundo volume de $O$ mundo como vontade e representação, "Sobre história", e, especialmente, o $\$ 153$ do segundo volume de Parerga e Paralipomena - para compor suas reflexões sobre a relação entre homem e animal desde uma perspectiva temporal no início da Extemporânea de $1874^{53}$.

52 Cf. LÖWITH, Karl. Nietzsche's Philosophy of the Eternal Recurrence of the Same. Trad. J. Harvey Lomax. Berkeley: University of California Press, 1997, p. 132.

53 Cf. MÜLLER-LAUTER, Wolfgang. Nietzsche. Sua filosofia dos antagonismos e os antagonismos

Cad. Nietzsche, Guarulhos/Porto Seguro, v.38, n.2, p. 57-95, maio/agosto, 2017. $\mid 77$ 
Nasser, E.

A esse respeito, Schopenhauer dirá que, por um lado, o animal, que está "completamente absorvido no presente", é mais satisfeito do que o homem com a existência, atormentado pelo tédio; mas, por outro lado, falta-lhe o prazer intelectual e, no limite, a história, que é o que faz do gênero humano uma humanidade ${ }^{\mathbf{5 4}}$. Uma outra fonte que pode ter fornecido contribuições nesse contexto, e que até agora não foi mencionada, é Emerson ${ }^{\mathbf{5 5}}$. Nos Essays, Emerson fala da rosa que se encontra debaixo de sua janela, "perfeita em cada momento de sua existência", ao contrário do homem, que adiando e lembrando, deixa de viver no presente; para Emerson, a imagem da rosa possui uma finalidade formadora, em antagonismo às tendências modernas, que cultuam passado e futuro ${ }^{\mathbf{5 6}}$, indicando que o homem não pode ser feliz e forte enquanto não "viver com a natureza no presente, acima do tempo ${ }^{57}$. Todavia, a fonte mais determinante para os pensamentos de Nietzsche sobre o assunto em debate, demandando um exame mais meticuloso, foi Leopardi.

Nos esboços do início da segunda Extemporânea, Nietzsche havia incluído um trecho do poema de Leopardi, chamado Canto

de sua filosofia. Trad. Clademir Araldi. São Paulo: Editora Unifesp, 2011, pp. 88 e 89. BRUSOTTI, Marco. Figure dela caducità. Nietzsche e Leopardi in: NEUMEISTER, Sebastian, SIRRI, Raffaele (Org.) Leopardi. Poeta e Pensatore / Dichter und Denker. Napoli: Alfredo Guida Editore, 1997, pp. 325 e 326 .

54 Cf. SCHOPENHAUER, Arthur. Die Welt als Wille und Vorstellung II in: Sämtliche Werke Band II. Frankfurt am Main: Suhrkamp, 1986, p. 571-573. Parerga und Paralipomena II in: Sämtliche Werke Band V. Frankfurt am Main: Suhrkamp, 1986, pp. 346-350.

55 Stack já chamou a atenção que quando Nietzsche escreve as Extemporâneas, incluindo aquela sobre história, ele está sendo muito influenciado por Emerson, já que o transcendentalista também aponta para os malefícios do excesso de passado. Cf. STACK, George. Nietzsche and Emerson. An Elective Affinity. Athens: Ohio University Press, 1992, pp. 104-137. Contudo, Stack não salienta a importância que Emerson, em seus pensamentos sobre a natureza sem tempo e o homem temporal, contida nos Essays, pode ter tido para Nietzsche na segunda Extemporânea.

56 Cf. GUTHRIE, James. Above Time. Emerson's and Thoureau's Temporal Revolutions. Columbia: University of Missouri Press, 2001, pp. 92-130.

57 EMERSON, Ralph Waldo. Emerson's Essays. New York: Charles Scribner's Sons, 1920, p. 88. Na cópia de Nietzsche, traduzida do inglês para o alemão por G. Fabrizius, essa passagem está contida na página 50 , mas sem anotações.

78 Cad. Nietzsche, Guarulhos/Porto Seguro, v.38, n.2, p. 57-95, maio/agosto, 2017. 
notturno di un pastore errante dell'Asia (Cf. Nachlass/FP, 29[98] e $30[2]$, KSA 7.677 e 725) ${ }^{\mathbf{5 8}}$, traçando explicitamente o vínculo entre os temas da anulação do passado e animalidade com Leopardi ${ }^{59}$. Esse poema, que no período deve ter exercido atração sobre Nietzsche e seus amigos mais próximos - numa troca de cartas com Nietzsche de outubro de 1873, Gersdorff usa Canto noturno para retratar o cenário melancólico de Siena no outono ${ }^{\mathbf{6 0}}$-, foi suprimido do manuscrito final, sendo incorporado como uma paráfrase. Essa decisão deve ter sido motivada mais por razões estilísticas do que filosóficas, já que no final da primeira seção dessa Extemporânea Nietzsche faz uma outra citação de Leopardi, retirada de $A$ se stesso $^{61}$. Pareceme, contudo, que originariamente a citação manifesta de Leopardi desempenhava uma função estratégica, de alguma forma diluída na versão definitiva dessa Extemporânea.

$\mathbf{5 8} \mathrm{O}$ trecho do poema recortado por Nietzsche, que usa a tradução do italiano para o alemão de Hamerling, é o seguinte:

Ach, wie muss ich dich beneiden!

Nicht nur weil frei du scheinest

Beinah von allen Leiden

Mühsal, Verlust, die schlimmste

Beängstigung im Augenblick vergessend -

Mehr noch, weil nie der Überdruss dich quälet!

(LEOPARDI, Giacomo. Leopardi’s Gedichte. Trad. Robert Hamerling. Leipzig: Bibliographischen Instituts, 1866, p. 94)

O fato de Nietzsche ter usado essa tradução é de particular importância para compreender o entrelaçamento entre instante e animalidade. Como nos mostra Bollnow, Hamerling traduz "subito scordi" por "im Augenblick vergessend", oferecendo a Nietzsche o conceito de instante, originariamente ausente no poema de Leopardi. Cf. BOLLNOW, Otto Friedrich. Nietzsche und Leopardi in: Zeitschrift für philosophische Forschung, 26, 1972, p. 68. Cf. também: BRUSOTTI, Marco. Figure dela caducità. Nietzsche e Leopardi in: NEUMEISTER, Sebastian, SIRRI, Raffaele (Org.) Leopardi. Poeta e Pensatore / Dichter und Denker. Napoli: Alfredo Guida Editore, 1997, p. 325 .

59 “1. Nenhuma consideração do passado. Animal - Leopardi” (Nachlass/FP, 29[97], KSA 7.676). 60 Cf. Carta de Carl von Gersdorff, dia 7 de outubro de 1873, KGB II, 4.313.

61 Cf. SALAQUARDA, Jörg. Op. cit., p. 27.

Cad. Nietzsche, Guarulhos/Porto Seguro, v.38, n.2, p. 57-95, maio/agosto, 2017. $\mid 79$ 
Nasser, E.

Comecemos colocando em evidência que Nietzsche, na época, possuía um conhecimento mais amplo de Leopardi, não se limitando a fazer um recorte ao acaso de uma de suas poesias. Após receber um convite entusiasmado de Hans Bülow, no final de 1874, para traduzir Leopardi para o alemão - Bülow presumia que Nietzsche poderia ser para Leopardi o que Schlegel foi para Shakespeare ${ }^{\mathbf{6}}$ -, Nietzsche recusa, justificando, para tanto, seu pouco domínio da língua italiana e falta de tempo. Nessa mesma carta ele relata o alcance de seu conhecimento da obra de Leopardi: apesar de conhecer uma parte muito pequena da obra em prosa, Nietzsche revela que um de seus amigos (Romundt ou Gersdorff) traduziu trechos da Operette Morali, suscitando-lhe, a cada vez, surpresa e admiração. Assim, além de estar familiarizado com as poesias, traduzidas por Hamerling, Nietzsche parece ter um conhecimento minimamente consistente dos escritos de Leopardi, interessando-se, inclusive, como diz a Bülow, por estudos monográficos a respeito do pensador italiano (ele faz alusão à obra Giacomo Leopardi, sa vie et ses oeuvres, de Auguste Bouché-Leclercq) (Cf. Carta para Hans von Bülow, dia 2 de janeiro de 1875 , KSB 5.3) ${ }^{\mathbf{6 3}}$. Pode-se com isso suspeitar que quando a citação de Canto noturno é inserida nas primeiras versões do início da segunda Extemporânea, Nietzsche era sabedor de que o trecho espelhava desafiadoras reflexões filosóficas de Leopardi sobre a condição humana, e supunha que o seu leitor estivesse inteirado disso.

62 Cf. Carta de Hans von Bülow para Nietzsche, dia 1 de novembro de 1874, KGB II, 4.601.

630 epistolário é bastante valioso nesse sentido, pois nos mostra que Nietzsche já havia travado contato com o nome de Leopardi muito antes de 1874. Cf. Carta de Erwin Rohde, dia 5 de novembro de 1869, KGB II, 2.73. Carta para Erwin Rohde, dia 11 de abril de 1872, KSB 3.306. Acrescentese que Gersdorff, numa carta a Rohde, diz que ele e Nietzsche, quando em Flims, em 1873, leem diariamente Leopardi. Cf. JANZ, Curt Paul. Friedrich Nietzsche: Biographie I. Munich: Hanser, 1993, p.691. A soma dessas informações faz com que eu não possa estar de pleno acordo com Brusotti quando diz que Nietzsche deveria ter um conhecimento escasso, ou mesmo nulo, da Operette morali. $C f$. BRUSOTTI, Marco. Figure dela caducità. Nietzsche e Leopardi in: NEUMEISTER, Sebastian, SIRRI, Raffaele (Org.) Leopardi. Poeta e Pensatore / Dichter und Denker. Napoli: Alfredo Guida Editore, 1997, p.331.

80 | Cad. Nietzsche, Guarulhos/Porto Seguro, v.38, n.2, p. 57-95, maio/agosto, 2017. 
Transfigurações do passado: aspectos do problema do tempo ...

Para Leopardi, a crise temporal que extenua o homem é derivada de sua experiência mórbida dos prazeres. $\mathrm{O}$ prazer, vinculado ao amor próprio e autopreservação, é uma virtualidade, fixado no passado ou no futuro, jamais no presente. A grande fonte de prazer para um adulto é de caráter retrospectivo (lembranças da infância), ou antecipatório, que, contudo, não pode ser verdadeiramente atingida. Essa fragmentação do desejo marca as distinções temporais, fazendo com que o homem, que busca vorazmente, e, em vão, o prazer, não se instale no presente, restando-lhe o permanente sofrimento e tédio. Essencialmente debilitado, o homem fantasia um retorno ao estado atemporal do animal. Além de Canto noturno - em Bruto Minore, por exemplo -, Leopardi fala sobre a admiração e inveja dos homens quando se defrontam com os animais; mas nunca admitindo a viabilidade de um reencontro real com esse estado perdido. Ao homem sofredor resta o sono, ópio ou, até mesmo, o suicídio ${ }^{64}$. Leopardi entende que o maior obstáculo para a restituição da animalidade perdida está na razão humana, inimiga da natureza, ainda que ele não deixe de vislumbrar o projeto da ultrafilosofia que, ao glorificar a imaginação, faria com que o homem ficasse mais próximo da natureza ${ }^{65}$.

Por conseguinte, ao citar Leopardi, Nietzsche espera não só assinalar com maior dramaticidade a situação do homem corroído pelo tempo através da comparação com o animal - ênfase que não está tão presente em Schopenhauer ${ }^{\mathbf{6 6}}$-, mas também indicar que o homem não pode ser transportado para o instante, como desejava

64 Cf. RENNIE, Nicholas. Speculating on the Moment. The Poetics of Time and Recurrence in Goethe, Leopardi, and Nietzsche. Göttingen: Wallstein Verlag, 2005, pp. 195-216.

$65 C f$. BINI, Daniela. Giacomo Leopardi's Ultrafilosofia in: Italica, vol. 74, 1, 1997, pp. 52-66. TEIXEIRA, Fábio Rocha. A crítica à Modernidade em Giacomo Leopardi: Em busca de uma ultrafilosofia. São Paulo: Humanitas, 2015, pp. 77-179.

66 Cf. BRUSOTTI, Marco. Figure dela caducità. Nietzsche e Leopardi in: NEUMEISTER, Sebastian, SIRRI, Raffaele (Org.) Leopardi. Poeta e Pensatore / Dichter und Denker. Napoli: Alfredo Guida Editore, 1997, p. 327.

Cad. Nietzsche, Guarulhos/Porto Seguro, v.38, n.2, p. 57-95, maio/agosto, 2017. 
Nasser, E.

Emerson. É justamente por esse motivo que, no trecho citado acima, Nietzsche diz que o homem quer viver como o animal, sem melancolia ou tédio, mas "não o quer como o animal". Ele não pode querer como o animal porque não há como anular a racionalidade, linguagem e temporalidade, inerentes à sua vida. Isso não quer dizer que a a-historicidade, pertencente ao animal, deva ser descartada enquanto ideal regulador. Com efeito, Nietzsche pensa a plausibilidade da a-historicidade tanto de um ponto de vista científico - sua contundente declaração a respeito da indistinção substancial entre homem e animal, trazida acima, faz com que se possa assumir que o homem deve compartir naturalmente com o animal a capacidade de se sentir a-histórico - como também ético. Esse horizonte ético está bastante presente no interesse de Nietzsche pelos cínicos nessa época; os cínicos são admirados por sua promoção da vida simples, desembaraçada dos constrangimentos impostos pela busca de prazeres, reproduzida através da observação dos animais, como o célebre caso de Diógenes que, na escuridão, busca inspiração no rato para triunfar sobre seus temores (Cf. Nachlass/FP, 31[10], KSA $7.752)^{67}$. Por isso Nietzsche dirá, na segunda Extemporânea, que a "felicidade do animal, como a do cínico perfeito, é a prova viva da justeza do cinismo". Todavia, se assim é, se a felicidade é obtida pelo homem mediante a imitação do animal, que esquece, isso só pode se dar "durante sua duração". O cinismo representa a tentação do retorno à natureza, à qual Rousseau (visto por Kant como um cínico) cedeu; mas não Nietzsche. Pois se o homem possui uma força de

67 Para Niehues-Pröbsting, Nietzsche representa o momento mais importante da recepção moderna do cinismo, tornando-se o modelo para o neocinismo. $C f$. NIEHUES-PRÖBSTING, Heinrich. The Modern Reception of Cynicism: Diogenes in the Enlightenment in: BRANHAM, R. Bracht, GOULETCAZÉ, Marie-Odile (Org.) The Cynics. The Cynic Movement in Antiquity and Its Legacy. Berkeley: University of California Press, 1996, pp. 354 e 363. Sobre a importância do cinismo para Nietzsche no período em que redige a segunda Extemporânea, Cf. JENSEN, Anthony. Nietzsche's Unpublished Fragments on Ancient Cynicism: The First Night of Diogenes in: BISHOP, Paul (Org.) Nietzsche and Antiquity. His Reaction and Response to the Classical Tradition. New York: Camden House, 2004, pp. 182-191.

82 | Cad. Nietzsche, Guarulhos/Porto Seguro, v.38, n.2, p. 57-95, maio/agosto, 2017. 
Transfigurações do passado: aspectos do problema do tempo ...

esquecimento, o que faz dele um parente do animal, ele não a possui com a mesma robustez. Caso o homem não pudesse esquecer, ele se depararia com a realidade do vir-a-ser em toda sua violência - ele seria como o "leal discípulo de Heráclito", um cratiliano, quase não se atrevendo mais a "levantar o dedo" (HL/Co. Ext. II, 1, KSA 1. 250). Porém, sua força de esquecimento não é total, não estando no retorno à natureza a solução definitiva para a crise iniciada pela percepção do tempo. O ponto é que a busca cínica pela felicidade tem como referência a vida do animal ao invés da vida do homem ${ }^{\mathbf{6 8}}$. O pleno esquecimento do animal é o "caminho mais curto para a felicidade"; mas de uma felicidade que "não possui muito valor" (Nachlass/FP, 29[143], KSA 7.694). Esse modelo de felicidade vale pouco para o homem porque, enquanto um ser essencialmente temporal, ele nunca poderá realmente alcançá-la (sem contar que a felicidade é, para o homem, uma meta indigna). Para o homem a plenitude a-histórica sequer é concebível com a morte, pois, nesse caso, o instante também cessa. “'Sentir-se histórico” significa saber que se nasceu para sofrer, e que todo nosso trabalho, na melhor das hipóteses, servirá para o esquecimento desse sofrimento" (Nachlass/ FP, 29[172], KSA 7.703).

Se o homem não pode esquecer completamente, qual o remédio para os danos provocados pelo tempo para sua vida? Essa foi uma questão que provocou grande inquietação para Nietzsche nos esboços da segunda Extemporânea, e ele seguramente não chegou a uma única resposta (Cf. Nachlass/FP, 29[90], 29[102], 29[124], 29[153], 29[157], 29[188], KSA 7. 672, 679, 687, 696, 697, 707). Em continuidade com os escritos precedentes, Nietzsche reforça sua convicção de que as potências supra-históricas da arte, filosofia e religião podem servir de antídoto para a ameaça do vir-a-ser; "com a palavra 'supra-

68 Sobre as diferentes acepções do conceito de vida na segunda Extemporânea, Cf. BULHOF, Ilse Nina. Op. cit., p. 29. Cf. também: JENSEN, Anthony. An Interpretation of Nietzsche's On the Uses and Disadvantage of History for Life. New York: Routledge, 2016, p. 43.

Cad. Nietzsche, Guarulhos/Porto Seguro, v.38, n.2, p. 57-95, maio/agosto, 2017. 
Nasser, E.

histórico’ denomino os poderes que desviam o olhar do vir-a-ser e o dirigem ao que dá à existência caráter de eterno e do estável em sua significação, para a arte e a religião" (HL/Co. Ext. II, 10, KSA 1. 330) ${ }^{69}$. O problema que ele passa a constatar nesse recurso, contudo, é que o homem, imerso na realidade do vir-a-ser, não pode efetivamente se inserir na eternidade senão momentaneamente, por exemplo, com o gozo estético, ocasionando, enfim, um aumento do pessimismo. Sentir a eternidade quando aprisionado ao processo, faz com que este seja forçosamente renunciado, pois, ao descerrar o sentido da vida, sabendo responder, “em uma hora do século um ou do século dezenove", "como e para que se viveu", o tempo que passa se torna o emblema da mesmice, acarretando no fastio e no nojo. Por isso que Nietzsche se permite, nesse momento, ser mais indeciso acerca dessa possibilidade para combater o vir-a-ser, demandando ser preciso deixar "o homem supra-histórico com seu nojo e sabedoria (HL/Co. Ext. II, 1, KSA 1. 256)". Ele começa a notar que o ponto de vista supra-histórico permanece demasiado teórico, é uma sabedoria, tendo pouca influência factível sobre a vida e, assim, não se emancipando realmente da atmosfera perversa que invadiu a cultura desde Sócrates.

A nova solução que será aventada por Nietzsche, mais condizente com um firme posicionamento prático, é a história a serviço da vida; "a história que se encontra a serviço da vida se encontra a serviço de um poder a-histórico" (HL/Co. Ext. II, 1, KSA 1.257). Essa fórmula, um tanto enigmática e paradoxal, é, na verdade, o desenvolvimento já maduro de antigas meditações sobre o valor da história. Numa anotação escrita entre 1868 e 1869, Nietzsche diz que nem tudo do passado possui valor para ser preservado e que o critério para preservação deve ser o seguinte: "tudo que ainda não perdeu sua força de efeito [Wirkungskraft] é valioso para a vida" (Nachlass/FP,

69 Nos fragmentos póstumos Nietzsche inclui a filosofia como uma das potências supra-históricas. Cf. Nachlass/FP, 29[194], KSA 7.709.

84 | Cad. Nietzsche, Guarulhos/Porto Seguro, v.38, n.2, p. 57-95, maio/agosto, 2017. 
Transfigurações do passado: aspectos do problema do tempo ...

74[11], KGW I, 5.91). Doravante, conferências e cursos insistem de forma cada vez mais veemente para a necessidade do filólogo educador, em oposição ao puro cientista, que incite uma retomada do passado com fins formadores, perseguindo a exemplaridade ideal (Cf. Homero e a filologia clássica, KGW II, 1. 249 e 250. Enciclopédia da filologia clássica, KGW II, 3. 376). Na segunda Extemporânea, Nietzsche avista nessa história valorativa o meio para remediar a modernidade deteriorada pelo excesso de vir-a-ser; o seu valor consiste no refreamento da voracidade do tempo (donde estar a serviço do poder a-histórico), algo perdido pela ciência histórica, que enxerga o passado como um fato, não um valor, imprimindo-lhe uma nociva imobilidade.

A discussão sobre o tipo de história capaz de transformar o estatuto do passado está especialmente concentrada num escrito póstumo do caderno U II 2.

Toda lembrança é uma comparação, quer dizer, identificação. Cada conceito nos diz isto: é o fenômeno "histórico" primordial. A vida demanda que se identifique o presente com o passado; uma certa violência, uma certa distorção que sempre está ligada à comparação. Eu designo esse instinto enquanto instinto para o clássico e exemplar: o passado serve de modelo [Urbild] para o presente. A ele se opõe o instinto antiquário, que se esforça em apreender o passado como passado, não impondo-lhe distorção ou idealização. A necessidade de viver requer o clássico; a necessidade de verdade requer o antiquário. $\mathrm{O}$ primeiro trata o passado com arte e força artística transfiguradora. Pense-se na outra perspectiva como superiora, então o passado deixa de agir como modelo e exemplo, pois ele cessa de ser um ideal, tornando-se uma realidade individual, tal como o presente mesmo se torna (Nachlass/FP, 29[29], KSA 7. 636).

Um primeiro aspecto interessante nessa anotação é que Nietzsche impõe uma fragmentação na concepção de repetição. 
Nasser, E.

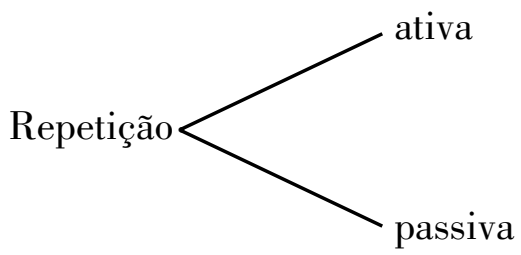

A repetição ativa se coaduna com a estrutura cognitiva do homem. A memória é uma forma primitiva de pensamento que busca por semelhanças, o que supõe um processo comparativo. Guiandose não por um desiderato teórico, mas prático, o intelecto molda o passado que deve cumprir, então, um papel organizador no presente; ele deve se tornar um modelo a ser imitado (Cf. Nachlass/FP, 19[217] e 19[226], KSA 7. 487, 489 e 490). Trata-se daquilo que Nietzsche chama de força plástica, uma força apropriadora do passado que viabiliza a idealização (Cf. HL/Co. Ext. II, 1, KSA 1. 251). Quando feito um ideal, o passado repetido influi ativamente sobre o presente, estabelecendo um laço de continuidade que faz, no limite, com que o passado deixe de ser passado. O homem se caracteriza por poder se lembrar do instante que passou; mas também possui a habilidade de retirar o passado de seu isolamento atômico, incorporando-o ao presente. $\mathrm{O}$ tipo de história que serve à vida, o fenômeno histórico primordial, nada mais é do que a manifestação do modo de ser originário da memória, portador de um poder intrinsicamente curativo que reverte o efeito perturbador da repetição do instante.

A crise do homem com o passado começa quando a força plástica fica debilitada mediante a preponderância do instinto antiquário que prioriza não a vida, mas a verdade. Com isso, a imitação cede lugar ao seu inverso: "a imitação é, nisto, o oposto do conhecer", pois rejeita toda "transposição" [Übertragung], aspirando unicamente à impressão "sem metáfora" e "sem consequência" (Nachlass/FP, 19[228], KSA 7.490 e 491). A repetição se torna passiva, a memória contemplativa ao invés de comparativa, e o 
Transfigurações do passado: aspectos do problema do tempo ...

passado rompe sua continuidade com o presente; o passado é, aqui, nada além do acúmulo observável de acontecimentos. É um fenômeno tipicamente moderno que intelectualiza a relação com o passado (prevalece o que Nietzsche compreende por interioridade sobre a exterioridade, o "cogito, ergo sum, mas não o vivo, ergo cogito" (HL/ Co. Ext. II, 10, KSA 1.329), subtraindo o seu valor e efeito. Em outras palavras, o passado vira objeto de conhecimento, sem laço vivo com o presente. Pense-se, por exemplo, numa religião, que, quando conhecida cientificamente, perde sua real relevância (HL/ Co. Ext. II, 7, KSA 1.296). Nietzsche oferece uma abordagem mais filosófica para o diagnóstico crítico que Burckhardt já havia feito acerca do caráter essencialmente emancipatório da modernidade, enxergando em sua ambição pelo progresso, e rejeição do elo com a tradição - cujo marco é a revolução francesa -, a condenação da cultura a um temerário estado de constante fluxo ${ }^{\mathbf{7 0}}$.

Nietzsche entende por antiquário a história que se pretende científica. Aqui é preciso, de antemão, alguma cautela com as noções e articulações concebidas no caderno U II 2 e na versão final da segunda Extemporânea. Em boa parte dos escritos preparatórios Nietzsche opera com a distinção entre as histórias monumental/ clássico - antiquária, desenvolvendo a conhecida tripartição que relativiza esses tipos de história pouquíssimo tempo antes do envio do manuscrito para o seu editor ${ }^{71}$. Fiquemos, portanto, com esse primeiro esquema, com o qual Nietzsche mais se ocupou: a história monumental ou clássica que idealiza o passado, servindo à vida, e a história antiquária que obedece aos desígnios da cultura teórica. Antiquário, ou cronológico, é o nome dado por Ranke à historiografia unicamente comprometida com a compilação de fatos, e Nietzsche certamente

70 Cf. HINDE, John R. Jacob Burckhardt and the Crisis of Modernity. Québec: McGill-Queen's University Press, 2000, p. 12.

71 Cf. SALAQUARDA, Jörg. Op. cit., p. 29. JENSEN, Anthony. An Interpretation of Nietzsche's On the Uses and Disadvantage of History for Life. New York: Routledge, 2016, pp. 14 e 15.

Cad. Nietzsche, Guarulhos/Porto Seguro, v.38, n.2, p. 57-95, maio/agosto, 2017. 
Nasser, E.

tinha em vista esse significado quando relaciona ciência histórica e história antiquária (ainda que Ranke empregue o conceito de maneira pejorativa) ${ }^{72}$. Esse tipo de história almeja ser um ramo independente de saber, guiado por uma rigorosa metodologia empirista, elaborada a partir do êxito do método histórico-crítico, que se opõe à filosofia, mais particularmente o método especulativo a priori da filosofia da história de Hegel. É pensando nessa concepção de historiografia que Nietzsche volta a insistir nas similitudes entre ciência histórica e ciência natural. Baseando-se numa passagem Ueber die Natur der Cometen, de Zöllner, ele traça um paralelo entre as ciências naturais e as disciplinas históricas, que unicamente recolhem e trivializam as experiências (Cf. Nachlass/FP, 29[24] e 29[92], KSA 7.635 e 672. HL/Co. Ext. II, 6, KSA 1.292) ${ }^{73}$. A aspiração é a objetividade científica no tratamento do passado, a absolvição das interferências subjetivas, inspirada pela figura da estética rankeana do historiador contemplativo, o que Nietzsche transformou no tema de reflexão crítica da seção 6 da segunda Extemporânea ${ }^{74}$. Mas o grande problema para o qual eu gostaria de chamar a atenção aqui é que, ao fazer do passado objeto de conhecimento, necessariamente se imprime racionalidade à história, que é o que anula seu poder efeitual. Na medida em que a ciência histórica analisa racionalmente o passado, é preciso assumir que "a razão a produziu" (Nachlass/FP, 29[31], KSA 7.637) ${ }^{\mathbf{7 5}}$, um

72 Cf. BEISER, Frederick. The German Historicist Tradition. Oxford: Oxford University Press, 2011, p. 254.

73 Schlechta e Anders dirão que, com esse paralelo, Nietzsche pretende fazer para as Geisteswissenschaften o que Zöllner faz para as Naturwissenschaften. Cf. SCHLECHTA, Karl, ANDERS, Anni. Friedrich Nietzsche. Von den verborgenen Anfängen seines Philosophierens. Stuttgart: Friedrich Frommann Verlag, 1962, p. 123.

$74 C f$. NASSER, Eduardo. Nietzsche et la réforme méthodologique de la philologie: le problème de la scientificité dans le contexte des études classiques in: DENAT, Céline, WOTLING, Patrick (Org.) Nietzsche. Les premiers textes sur les Grecs. Reims: Épure, 2016, pp. 70-72.

75 Essa formulação de Nietzsche é subsidiada pela metodologia crítica, guiada por uma diretriz racionalista, empregada por Ranke. Porém, Ranke, graças à sua tese acerca da inefabilidade do individual, foi também visto por muitos como um irracionalista. Sobre esse tema, $C f$. BEISER, Frederick. Op. cit., pp. 284-288.

88 Cad. Nietzsche, Guarulhos/Porto Seguro, v.38, n.2, p. 57-95, maio/agosto, 2017. 
Transfigurações do passado: aspectos do problema do tempo ...

inesperado ponto de encontro entre ciência histórica e filosofia da história hegeliana que confirmam, por vias metodologicamente distintas, o fim racional da história ${ }^{76}$. Mas ao submeter o passado à racionalização, não só a natureza genuína das sucessões é falsificada - "falamos de causalidade quando nós somente vemos no fundo uma sucessão de acontecimentos" (Nachlass/FP, 29[8], KSA 7. 625) -, como as causas passam a ter mais prioridade do que os efeitos, o que forçosamente singulariza um acontecimento do passado. Um complexo de causa e efeito verdadeiramente conhecido do passado é desprovido do "efeito em si" (Effect an sich) da história monumental, restando o reconhecimento de que "jamais poderia acontecer algo inteiramente igual no jogo de dados do futuro e do acaso" (HL/Co. Ext. II, 2, KSA 1. 262). O cientista histórico, ao priorizar o conhecimento causal, aniquila a imitação, pois já se sabe que todo acontecimento não pode ser o mesmo numa segunda vez, o inverso da história monumental que "subtrai as causas" (Nachlass/FP, 29[34], KSA 7. 639). Temos aqui a diferença entre o ângulo idealista e científico; enquanto a idealização despreza a multiplicidade de motivos, sendo um emblema da eternidade, a ciência, ao buscar por causas, "vê por toda parte algo que veio a ser, algo histórico, e nunca um ente, o eterno" (HL/ Co. Ext. II, 10, KSA 1.330). Com isso, o passado perde sua conexão efetiva com o presente, não sendo senão algo para ser apaticamente contemplado, como "quadros numa galeria" (Nachlass/FP, 29[36], KSA 7.640), o que somente intensifica sentimento de velhice da humanidade constrangida por um tempo absoluto que passa. $\mathrm{O}$ uso abusivo da racionalidade, a incessante ânsia por verdade, é, enfim, o grande obstáculo para que se atinja o heroísmo, estado superior à mera felicidade, germinado pelo idealismo, que, como dirá Nietzsche pouco depois na terceira Extemporânea, é o que não deixa o homem

76 A segunda Extemporânea seguramente não se limita a uma interlocução crítica com o que comumente é chamado de ciências históricas, travando igualmente um embate com as filosofias da história de Hegel e Hartmann nas seções 8 e 9. Trata-se de um escopo mais amplo de discussão que não pretendo tocar nesse artigo.

Cad. Nietzsche, Guarulhos/Porto Seguro, v.38, n.2, p. 57-95, maio/agosto, 2017. 
Nasser, E.

ser um brinquedo nas mãos do tempo, "essa grande criança" (SE/ Co. Ext. III, KSA 1.374).

\section{Conclusão}

Vimos que Nietzsche, na segunda Extemporânea, e também em anotações preparatórias dessa obra, requer um tipo de história valorativa para conter a repercussão atroz do tempo, encontrando um caminho alternativo para a solução cada vez mais controversa de recursos supra-históricos. É nesse cenário que foi imperioso combater a ciência histórica, que, ao ver no passado um fato, e não um valor, liquida seu poder de efeito sobre o presente, o entrelaçamento necessário para a anulação da percepção do vir-a-ser. Destarte, Nietzsche está aqui mais preocupado em proteger filosoficamente um tipo de historiografia dominante até o século XVIII - em que a narrativa histórica guardava proximidade com a ficcional, sendo seus fins pedagógicos -, do que propriamente elaborar uma nova concepção de história. Não há dúvida de que Nietzsche está, assim, promovendo uma perspectiva vigorosamente antimoderna. Entretanto, é preciso apontar que estamos lidando com uma fase em que o pensamento nietzschiano já está passando por crescentes oscilações, de modo que a sua campanha antimoderna não está eximida de inconsistências. Basta, nesse sentido, consultar a seção 8 da segunda Extemporânea, quando Nietzsche condena os resquícios de medievalismo que impregnam a história, com sua perturbadora necessidade de cultuar o passado, impedindo o florescimento da esperança para com o futuro. Nessa obra já existem indícios, ainda que exíguos, de uma apreciação de valores modernos que prestigiam o processo, ao lado de uma exacerbação da necessidade de esquecimento, prenúncios de uma virada que atingiria seu momento culminante nos anos subsequentes.

$90 \mid$ Cad. Nietzsche, Guarulhos/Porto Seguro, v.38, n.2, p. 57-95, maio/agosto, 2017. 
Transfigurações do passado: aspectos do problema do tempo ...

\section{Referências bibliográficas}

BAMBACH, Charles. Heidegger, Dilthey and the Crisis of Historicism. Ithaca: Cornell University Press, 1995.

BEISER, Frederick. The German Historicist Tradition. Oxford: Oxford University Press, 2011.

BENJAMIN, Walter. Über den Begriff der Geschichte in: Gesammelte Schriften I. Frankfurt am Main: Suhrkamp, 1994.

BINI, Daniela. Giacomo Leopardi’s Ultrafilosofia in: Italica, vol. 74, 1, 1997.

BOLLNOW, Otto Friedrich. Nietzsche und Leopardi in: Zeitschrift fuir philosophische Forschung, 26, 1972.

BROBJER, Thomas. Nietzsche's View of the Value of Historical Studies and Methods in: Journal of the History of Ideas, 65, 2, 2004.

. Nietzsche's Relation to Historical Methods and Nineteenth-Century German Historiography in: History and Theory, 46, 2007.

BRUSOTTI, Marco. Figure dela caducità. Nietzsche e Leopardi in: NEUMEISTER, Sebastian, SIRRI, Raffaele (Org.) Leopardi. Poeta e Pensatore / Dichter und Denker. Napoli: Alfredo Guida Editore, 1997.

. Heidegger su storia monumentale e ripetizione. La seconda Considerazione Inattuale di Nietzsche in Essere e Tempo in: Metafisica e nichilismo. Löwith e Heidegger interpreti di Nietzsche. Bologna: Pendragon, 2006.

BULHOF, Ilse Nina. Apollos Wiederkehr. Eine Untersuchung der Rolle des Kreises in Nietzsches Denken über Geschichte und Zeit. Den Haag: Martinus Nijhoff, 1969.

DILTHEY, Wilhelm. Die drei Grundformen der Systeme in der ersten Hälfte des 19.Jahrhunderts in: Gesammelte Schriften Band IV. Stuttgart/Göttingen: B.G. Teubner/Vandenhoeck \& Ruprecht, 1974.

EMDEN, Christian J. Friedrich Nietzsche and the Politics of History. Cambridge: Cambridge University Press, 2008.

EMERSON, Ralph Waldo. Emerson's Essays. New York: Charles Scribner's Sons, 1920.

FIGL, Johann. Nietzsche und die philosophische Hermeneutik des 20.Jahrhunderts. Mit besonderer Berücksichtung Diltheys, Heideggers und Gadamers in: Nietzsche Studien, 10/11, 1981/82. 
Nasser, E.

FLEISCHER, Margot. Die Zeitlichkeit des Menschen. Nietzsche Analyse in seiner zweiten Unzeitgemässen Betrachtung in: BEIERWALTES, Werner, SCHRADER, Wiebke (Hrsg.) Weltaspekte der Philosophie. Rudolf Berlinger zum 26. Oktober 1972. Amsterdam: Rodopi NV, 1972.

GENT, Werner. Die Raum-Zeit-Philosophie des 19.Jahrhunderts II. Die Geschichte der Begriffe des Raumes und der Zeit vom kritischen Kant bis zur Gegenwart. Hildesheim: Georg Olms, 1971.

GUILLAND, Antoine. Modern Germany \& Her Historians. New York: Mcbride, Nast \& Company, 1915.

GUTHRIE, James. Above Time. Emerson's and Thoureau's Temporal Revolutions. Columbia: University of Missouri Press, 2001.

HEIDEGGER, Martin. Sein und Zeit in: Gesamtausgabe Band 2. Frankfurt am Main: Vittorio Klostermann, 1977.

. Nietzsche I in: Gesamtausgabe Band 6.1. Frankfurt am Main: Vittorio Klostermann, 1996.

. Was heisst Denken? In: Gesamtausgabe Band 8. Frankfurt am Main: Vittorio Klostermann, 2002.

. Zur Auslegung von Nietzsches II. Unzeitgemässer Betrachtung: "Vom Nutzen und Nachteil der Historie für das Leben" in: Gesamtausgabe Band 46. Frankfurt am Main: Vittorio Klostermann, 2003.

. Der Begriff der Zeit in: Gesamtausgabe Band 64. Frankfurt am Main: Vittorio Klostermann, 2004.

HINDE, John R. Jacob Burckhardt and the Crisis of Modernity. Québec: McGillQueen's University Press, 2000.

HORKHEIMER, Max. Zu Bergsons Metaphysik der Zeit in: Gesammelte Schriften Band 3. Frankfurt am Main: Fischer Taschenbuch, 1988.

JANZ, Curt Paul. Friedrich Nietzsche: Biographie I. Munich: Hanser, 1993.

JENSEN, Anthony. Nietzsche's Unpublished Fragments on Ancient Cynicism: The First Night of Diogenes in: BISHOP, Paul (Org.) Nietzsche and Antiquity. His Reaction and Response to the Classical Tradition. New York: Camden House, 2004.

. An Interpretation of Nietzsche's On the Uses and Disadvantage of History for Life. New York: Routledge, 2016.

92 | Cad. Nietzsche, Guarulhos/Porto Seguro, v.38, n.2, p. 57-95, maio/agosto, 2017. 
Transfigurações do passado: aspectos do problema do tempo ...

KAUfMANN, Walter. Nietzsche. Philosopher, Psychologist, Antichrist. Princeton: Princeton University Press, 1974.

KRUMMEL, Richard Frank. Nietzsche und der deutsche Geist I. Berlin/New York: Walter de Gruyter, 1998.

LEOPARDI, Giacomo. Leopardi’s Gedichte. Trad. Robert Hamerling. Leipzig: Bibliographischen Instituts, 1866.

LÖWITH, Karl. Nietzsche’s Philosophy of the Eternal Recurrence of the Same. Trad. J. Harvey Lomax. Berkeley: University of California Press, 1997.

MASSEY, Heath. The Origin of Time. Heidegger and Bergson. New York: Suny Press, 2015.

MCFARLAND, James. Constellation. Friedrich Nietzsche and Walter Benjamin in the Now-Time of History. New York: Fordham University Press, 2013.

MÜLLER-LAUTER, Wolfgang. Nietzsche. Sua filosofia dos antagonismos e os antagonismos de sua filosofia. Trad. Clademir Araldi. São Paulo: Editora Unifesp, 2011.

NASSER, Eduardo. Sul cristianesimo del giovane Nietzsche in: BUSELLATO, Stefano (Org.) Nietzsche dal Brasile. Contributi alla ricerca contemporanea. Pisa: Edizioni ETS, 2014. . Nietzsche e a ontologia do vir-a-ser. São Paulo: Loyola, 2015.

. Nietzsche et la réforme méthodologique de la philologie: le problème de la scientificité dans le contexte des études classiques in: DENAT, Céline, WOTLING, Patrick (Org.) Nietzsche. Les premiers textes sur les Grecs. Reims: Épure, 2016.

NIEHUES-PRÖBSTING, Heinrich. The Modern Reception of Cynicism: Diogenes in the Enlightenment in: BRANHAM, R. Bracht, GOULET-CAZÉ, Marie-Odile (Org.) The Cynics. The Cynic Movement in Antiquity and Its Legacy. Berkeley: University of California Press, 1996.

NIETZSCHE, F. Sämtliche Werke. Kritische Gesamtausgabe (KGW). Berlin/New York: Walter de Gruyter, 1967 - 1978.

. Nietzsche Briefwechsel. Kritische Gesamtausgabe (KGB). Berlin/New York: Walter de Gruyter, 1975.

. Sämtliche Briefe: Kritische Studienausgabe (KSB). Berlin/ New York: Walter de Gruyter, 1986.

Cad. Nietzsche, Guarulhos/Porto Seguro, v.38, n.2, p. 57-95, maio/agosto, 2017. |93 
Nasser, E.

. Sämtliche Werke. Kritische Studienausgabe (KSA). Berlin/New York: Walter de Gruyter, 1999.

REICH, Hauke. Rezensionen und Reaktionen zu Nietzsches Werken 1872 - 1889. Berlin/New York: Walter de Gruyter, 2013.

RENNIE, Nicholas. Speculating on the Moment. The Poetics of Time and Recurrence in Goethe, Leopardi, and Nietzsche. Göttingen: Wallstein Verlag, 2005.

SALAQUARDA, Jörg. Studien zur Zweiten Unzeitgemässen Betrachtung in: Nietzsche Studien, 13, 1984.

SCHLECHTA, Karl, ANDERS, Anni. Friedrich Nietzsche. Von den verborgenen Anfängen seines Philosophierens. Stuttgart: Friedrich Frommann Verlag, 1962.

SCHLEGEL, Wolfgang. Nietzsches Geschichtsauffassung. Würzburg: Konrad Triltsch, 1937.

SCHNÄDELBACH, Herbert. Philosophy in Germany 1831 - 1933. Trad. Eric Matthews. Cambridge: Cambridge University Press, 2009.

SCHOPENHAUER, Arthur. Die Welt als Wille und Vorstellung I in: Sämtliche Werke Band I. Frankfurt am Main: Suhrkamp, 1986.

. Die Welt als Wille und Vorstellung II in: Sämtliche Werke Band II. Frankfurt am Main: Suhrkamp, 1986.

. Parerga und Paralipomena II in: Sämtliche Werke Band V. Frankfurt am Main: Suhrkamp, 1986.

STACK, George. Nietzsche and Emerson. An Elective Affinity. Athens: Ohio University Press, 1992.

STAMBAUGH, Joan. Untersuchungen zum Problem der Zeit bei Nietzsche. Den Haag: Martinus Nijhoff, 1959.

STEGMAIER, Werner. Philosophie der Fluktuanz. Dilthey und Nietzsche. Göttingen: Vandenhoeck \& Ruprecht, 1992.

TEIXEIRA, Fábio Rocha. A crítica à Modernidade em Giacomo Leopardi: Em busca de uma ultrafilosofia. São Paulo: Humanitas, 2015.

TROELTSCH, Ernst. Der Historismus und seine Probleme. Erstes Buch: Das logische Problem der Geschichtsphilosophie. Tübingen: J.C.B. Mohr, 1922.

94 | Cad. Nietzsche, Guarulhos/Porto Seguro, v.38, n.2, p. 57-95, maio/agosto, 2017. 
Transfigurações do passado: aspectos do problema do tempo ...

Abstract: The Second Untimely Meditations was received within the philosophical contemporary scene as a singular work of the nietzschean thought, which serves as a turning point from the abstract time to the experienced time; his greatest virtue would have been to evidence the future as a dominant temporal mode in the human existence. Although, I intend to show that, in this work, Nietzsche is in fact interested in combating the devastating effects of the perception of time to man - a problem that already followed him - finding, for this, precious resources in a valued appropriation of History.

Key words: time - becoming - History - value - Science causality.

Artigo recebido para publicação em 21/01/2017. Artigo aceito para publicação em 16/05/2017. 